\title{
INVESTIGATING READINESS ATTITUDE TOWARD USING MOBILE PAYMENT SYSTEMS THROUGH TECHNOLOGY ACCEPTANCE MODEL
}

\author{
Asrul Sani ${ }^{*}$ ), Nur Nawaningtyas Pusparini ${ }^{2}$, Agus Budiyantara ${ }^{3}$, Irwansyah ${ }^{4}$, Anton Hindardjo 5 \\ Informatics \\ Sekolah Tinggi Manajemen dan Ilmu Komputer Widuri \\ asrulsani@kampuswiduri.ac.id ${ }^{1 *}$; tyaspusparini@kampuswiduri.ac.id 2; \\ agusbudiyantara@kampuswiduri.ac.id 3; irwansyahsf07@gmail.com 4 \\ Management \\ Sekolah Tinggi Ekonomi Islam SEBI \\ anton.hindardjo@sebi.ac.id 5 \\ ${ }^{*}$ ) Corresponding Author
}

\begin{abstract}
Abstrak
Perkembangan mobile payment sejalan dengan meningkatnya para pengembang aplikasi dalam membuat fitur yang mudah dalam menggunakan aplikasi tersebut. Kesiapan pengguna dalam menggunakan mobile payment dalam melakukan transaksi menjadi hal utama, apakah pengguna mempercayai aplikasi yang digunakan dalam bertransaksi. Penelitian ini mencoba untuk memodelkan sebuah framework dimana model yang digunakan adalah technology readiness index dan technology acceptance model. Responden penelitian berada di Jakarta dengan teknik purpose sampling yang berjumlah 204. Pengolahan data menggunakan aplikasi SPSS dan SmartPls 3.0. Hasil penelitian memberikan pengetahuan tentang tingkat kesiapan dalam penggunaan aplikasi mobile payment memunculkan sikap optimism, namun tidak dari segi keamanan. Pengguna masih merasa bahwa mobile payment masih tidak aman untuk melakukan transaksi secara online.
\end{abstract}

Kata kunci: TAM. Readiness, Mobile Payment, SEM

\section{Abstract}

The development of mobile payments is in line with the increasing number of application developers making features that are easy to use. The readiness of users to use mobile payments in making transactions is the main thing, whether users trust the applications used in transactions. This study attempts to model a framework where the technology readiness index and the technology acceptance model are used. Respondents in the study were in Jakarta with a purposive sampling technique, amounting to 204. Data processing used SPSS and SmartPls 3.0 applications. The results of this study provide knowledge about the level of readiness in using the mobile payment application, giving rise to an attitude of optimism, but not from a security perspective. Users still feel that mobile payments are still not safe to make transactions online.

Keywords: TAM, Readiness, Mobile Payment, SEM.

\section{INTRODUCTION}

According to business theory, all organizations must consider three types of assumptions affecting their way of doing work: assumptions about the organizational environment, Assumptions about mission accomplishment., Assumptions about the competencies and resources that enable mission fulfilment (Drucker, 2017; Veblen \& Dowd, 2017)
However, the theory must be reconsidered in the future, especially if the organization has experienced great success or failure. The COVID-19 pandemic has revealed significant flaws in many SMEs' current business models and operations (Daly \& Walsh, 2010)

In today's digital era, a cashless lifestyle in the future, or even for the present in many countries. In Indonesia, cashless or cashless forms of payment, using cards as payment instruments, and the circulation of many financial technology 
applications have become a new trend in making transactions by the public. Many business players, including banks and telecommunication companies, are innovating to reach more significant customers (Abbas, 2017).

One application that supports this technology is OVO. OVO is e-money from Bank Nobu that can be used as an electronic payment tool for all services and purchases of goods to providers of goods and other SMEs that work with OVO. OVO provides various types of balance replenishment for its customers; apart from using banks, customers can also top up their OVO balances through several partner banks. Another advantage that OVO has is its use, which can be used to pay for food installs. The emergence of OVO certainly has an impact on the intention of consumers to use it. The intention to use this is of course, based on consumer attitudes before using electronic payments (Kusuma \& Darma, 2020)

Several factors can influence attitudes towards the intention to use, some of which are perceived benefits, perceived convenience, and risk perceptions. This study combines the Theory of Technology readiness and the Technology Acceptance Model (TAM), a general model that describes a person's behavior in responding to technology (Davis, 1989; Faisal, Handayanna, \& Purnamasari, 2021). Two critical things that encourage one's intention to use technology are perceived usefulness and perceived ease to use. In perceived usefulness, OVOs can make payments in the GRAB application and can be used to pay for purchase transactions at store/restaurant outlets that are registered as OVO business partners with the QR code scanning method. Other advantages or benefits with transactions using OVO, namely, consumers get cashback in the range of $20 \%-50 \%$ on business partners and GRAB services with special terms and conditions .

You can make OVO payments at merchants by scanning the QR Code first, usually displayed at stores or merchants. What distinguishes here is the consumer who enters the payment amount, then enters the secret six-digit pin to confirm the payment. In fact, there are still many consumers who have the GRAB application, but they rarely use the OVO feature to make payments to cooperating merchants. This is because the system's operation sometimes seems complicated where it is necessary to scan a QR code, and not everyone understands how to use it. Lack of socialization on the use of QR codes also requires sellers to explain to their consumers how to use QR codes on OVO. In addition, some consumers usually experience transaction difficulties due to signal reasons, both signals from the consumer's internet and signals from the EDC system (Pesik, Worang, \& Arie, 2020)

In relation to the acceptance of new technology systems, specifical payment via OVO, Davis (1989) developed the Theory of Acceptance Model (TAM), which states that system use is influenced by behavioral intention, which is influenced by user-perceived usefulness and perceived ease of use. According to the Technology Acceptance Model (TAM), which is an adaptation of the Theory of Reasoned Action (TRA), technology use is influenced by behavioral intention, which is controlled by user beliefs, specifically perceptions of system usefulness (perceived usefulness) and perceived ease of use. Use of the system (perceived ease of use) (A. H. Nugroho, Bakar, \& Ali, 2017; Zhao, Xue, Jin, Li, \& He, 2016)

This research will look at the phenomenon, how is the readiness to use mobile payments, in this case, OVO, on SMEs by combining the models from the Readiness Index Technology with the TAM model and what are the factors that affect the readiness of SMEs in making payment transactions using OVO, so that OVO providers can find out the readiness of SMEs in using mobile-based payments

Initially, TAM included attitude toward using variables but later excluded it because of its weak role in mediating the relationship between the desire to use and user beliefs (Venkatesh, Thong, \& $\mathrm{Xu}, 2016)$. Based on TAM, when technology is considered valuable and easy to use, this will give rise to a positive influence attitude and desire to use technology and lead to the acceptance and actual use of the technology (Salloum \& Al-Emran, 2018). TAM has become a widely used model for predicting attitudes, desires, and behaviors in using new technologies. This model explains about $40 \%$ of the variance of an individual's willingness to use information technology (Venkatesh, Morris, Davis, \& Davis, 2003; Venkatesh et al., 2016). Individual characteristics become one of the centers of attention in determining factors that affect a person's acceptance of the new information system. One of them is the Technology Readiness Index (TRI) developed by (Parasuraman, 2000). (A. Parasuraman 2014; Parasuraman \& Colby, 2015) define technology readiness as "people propensity to embrace and use new technologies for accomplishing goals in home life at the workplace". They argue that a person's perception of technology has a positive side and a negative side, causing the emergence of four dimensions in technology readiness: optimism, innovativeness, discomfort, and insecurity. Research on technology readiness 
has been done a lot. Research by Walczuch et al (2007) on 810 employees at a financial service provider shows that individual characteristics in the technology readiness dimension affect user perceptions. But surprisingly, the innovativeness dimension shows a negative influence on the perception of the usefulness of technology (Pratiwi \& Indriani, 2017)

Research by Nugroho et al (2015) found that innovativeness, discomfort, and insecurity did not affect perceived convenience or perceived benefits of technology. Optimism has a positive effect on perceived benefits but does not affect perceived ease of use of technology. Perceived benefits influence interest in using technology but not by perceptions of ease of use of technology (M. A. Nugroho, 2015). Different research results create interest in research in the acceptance of other technologies and other research subjects, such as the acceptance of technology at SMEs . The optimism dimension denotes a positive attitude toward technology and perception of the benefits of technology in increasing work efficiency and improving performance at work and at home. Optimists understand that good and bad things will come and go in life. They choose to spend their time doing things that are active to achieve positive results, which gives more effective outcomes than pessimists. Optimistic people tend to prevent themselves from stress and worry about bad experiences and the risks that might happen to something. When dealing with new technology, optimism causes a person to think positively about the results obtained and avoid worrying about the negative outcomes that may arise from new technology . People who have an optimistic attitude believe that benefits will always be present in the emergence of new technologies, such as convenience, the flexibility of time, mobility, and stimulation. Thus, optimism will make it easier for someone to feel the benefits of new technology and find new technology easy to use.

\section{RESEARCH METHODS}

The sampling technique used was purposive sampling technique with a sample of 204 respondents and the research object of the OVO digital payment service. In comparison, the subjects in this study are users of the OVO digital payment service domiciled in Jakarta. This study uses data collection techniques in the form of communication techniques with an online questionnaire instrument. Data processing using SPSS Statistics 22 and SmartPLS 3.0 software. After that, a literature study was carried out by studying similar research that has been carried out in previous research studies (Sani \& Wiliani, 2019)

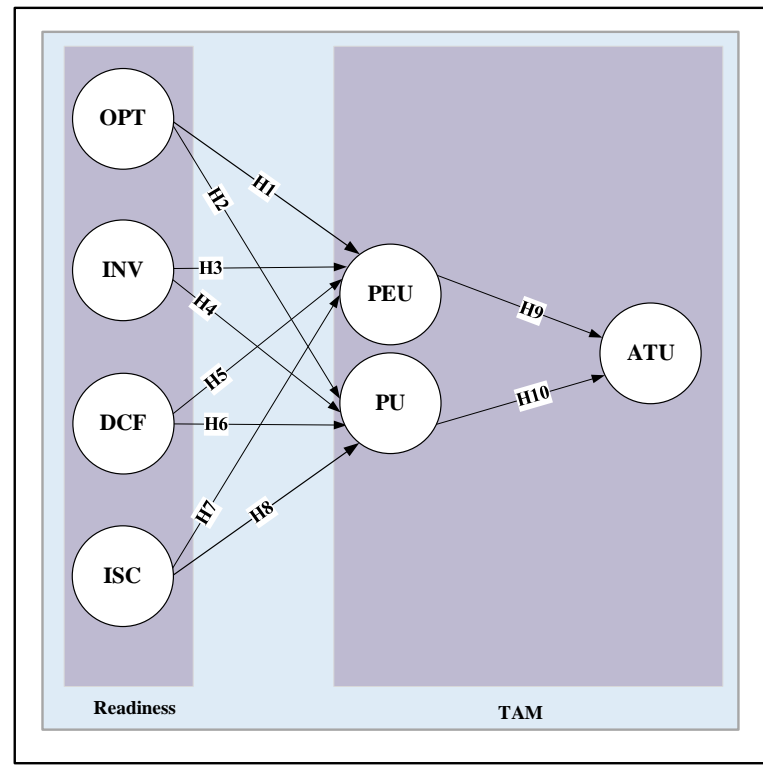

Source: (Sani, Nawaningtyas, Budiyantara,

Irwansyah, \& Hindardjo, 2021)

Figure 1. Research Model

This research uses a quantitative approach, namely research using data analysis in the form of numbers that allows the researcher to test a particular hypothesis or theory. The research model used is combining the TRI model with the TAM model.

The technology readiness index consists of 4 (four) variables consisting of Optimism (OPT), Innovativeness (INV), Discomfort (DCF), and Insecurity (ISC). TAM model has three variables: perceived ease of use (PEU), perceived usefulness (PU), and attitude toward using (ATU).This can be seen in Figure 1, which is the research model (Acheampong et al., 2017; Sinha, Majra, Hutchins, \& Saxena, 2019)

A five-point Likert scale was used in measuring the questionnaire (Kam, 2020). The level of the assessment starts from "strongly disagree" with a value of one to "strongly agree" with a value of five. To ensure that the validity and reliability of this study runs correctly, several indicator items were adopted from several previous studies, which are the references of this study (Husain, Sani, Ardhiansyah, \& Wiliani, 2020)

This research was carried out into six stages of the procedure, which are procedurally shown in Figure 2, which includes: Initial study, modeling, design, measurement \& structural 
testing, then continued by analyzing and producing reports published.

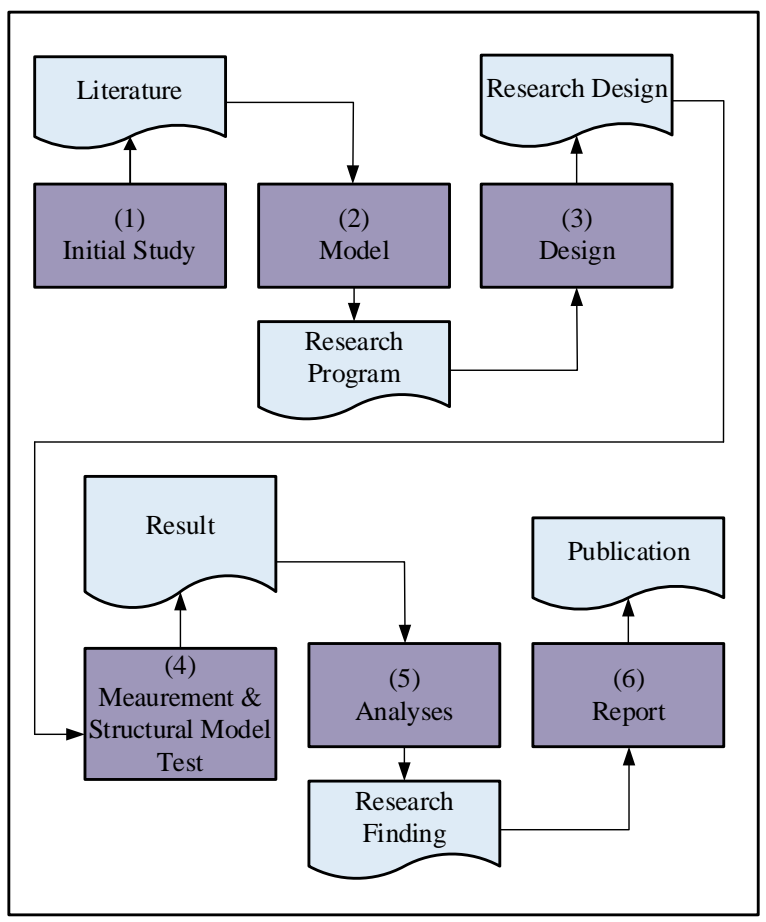

Source: (Sani et al., 2021)

Figure 2. Research Procedure

The initial study was to collect papers related to the research and then create a model by adapting two related models, namely readiness technology and TAM. The resulting model is then made a list of questions and questionnaire statements distributed to respondents. After the respondents who filled out the questionnaire were collected, measurement testing was carried out, and then structural testing was continued if the measurement test met the requirements. The test results are then analyzed to obtain material for discussion, which will then be made a report that will be published later.

This study's instrument was a questionnaire with three parts: the first was cover letters from researchers to respondents, the second was a cover sheet with a brief explanation of research activities, and the third was a research question sheet.

\section{RESULTS AND DISCUSSION}

The Assessment will be carried out in two stages: testing the outer model or commonly called the measurement model, and testing the inner model known as the structural model

\section{Measurement model (outer model)}

This evaluation is carried out to assess the validation and reliability of the model. An outer model with reflective indicators is assessed using convergent and discriminatory indicators that form latent constructs, as well as composite reliability and Cronbach alpha for the indicator block.

\section{Convergent Validity.}

Convergent validity relates to the principle that the gauges of a construct must be highly correlated. The loading factor of the indicators, which measures the construct, is used to evaluate the convergence test in PLS with reflective indicators. The rule of thumb used for convergent validity is an outer loading of $>0.7$ (Hair Jr, Hult, Ringle, \& Sarstedt, 2016; Willy Abdillah, 2015)

\section{Discriminant Validity}

Discriminant validity relates to the principle that measures of different constructs should not be highly correlated. Discriminant validity occurs when two different instruments measure two uncorrelated constructs, yielding uncorrelated scores. The discriminant validity test is assessed based on the cross-loading value of the measurement with the construct. Another method for assessing discriminant validity is to compare the AVE roots for each construct with the correlation between constructs and other constructs. The recommended cross-loading value for each variable must be> 0.7 in one variable, AVE root> latent variable correlation (A Subiyakto, 2018; A. a. Subiyakto, 2017)

\section{Composite Reliability}

Performing a reliability test is done to measure the consistency of the measuring instrument interval. Reliability shows the accuracy, consistency, and accuracy of a measuring instrument in making measurements. Reliability test in partial least square (PLS) uses two methods, namely Cronbach's alpha and composite reliability. Cronbach's alpha measures the lower limit of the reliability value of a construct, while Composite reliability measures the real value of the reliability of a construct. The rule of thumb for alpha or composite reliability values must be greater than 0.7 (Hair, Sarstedt, Ringle, \& Mena, 2012; Aang Subiyakto, Ahlan, Kartiwi, \& Putra, 2016).

The three components above, shown in table 1, show eight indicators that are rejecting, namely OPT1, OPT3, INV1, DCF1, ISC1, PU5, ATU3, and ATU4. This indicator is then no longer used when performing structural testing. Based on the 
JURNAL RISET INFORMATIKA

Vol. 3, No. 3 June 2021

Average Variance Extracted (AVE) test, all constructs are above the specified threshold, as well as for Cronbach's Alpha (CA) and Composite Reliability (CR) tests, and all constructs are above the specified number which is above 0.7 (Hair et al., 2012; Husain \& Sani, 2020). The coefficient of determination $\left(\mathrm{R}^{2}\right)$ purpose of this test is to measure how the latent dependent variable explains many variations in the latent dependent variable, the value of the determinant coefficient is said to be good if the value of $R^{2}$ is $\geq 0.70$

The value of $\mathrm{R}^{2}$ shows the contribution of the influence of each readiness construct on the TAM construct. In Table 1 , it can be seen that the $\mathrm{R}^{2}$ value of the PEU construct is 0.760 , this means that the contribution of the influence of OPT, INV, DCF, and ISC to PEU is $76 \%$. The contribution of the influence of OPT, INV, DCF, and ISC to PU was $60.1 \%$, and the contribution of the influence of PEU and PU to ATU was $14.4 \%$.

The analysis obtained from the measurement of the outer model is that all constructs are valid and reliable to be continued with the inner model measurement if seen from the minor contribution of influence is the influence between PEU and PU on ATU, which indicates that there are still respondents who know there are deficiencies in the OVO application their use.

Table 1. Statistical Analysis

\begin{tabular}{|c|c|c|c|c|c|}
\hline $\begin{array}{l}\text { Indi } \\
\text { cator }\end{array}$ & $\begin{array}{c}\text { Outer } \\
\text { Loading }\end{array}$ & AVE & CA & CR & $\mathrm{R}^{2}$ \\
\hline OPT1 & Reject & & & & \\
\hline OPT2 & 0.778 & & & & \\
\hline OPT3 & Reject & 0.535 & 0.783 & 0.851 & \\
\hline OPT4 & 0.735 & & & & \\
\hline OPT5 & 0.779 & & & & \\
\hline INV1 & Reject & & & & \\
\hline INV2 & 0.815 & & & & \\
\hline INV3 & 0.904 & 0.701 & 0.891 & 0.921 & \\
\hline INV4 & 0.867 & & & & \\
\hline INV5 & 0.888 & & & & \\
\hline DCF1 & Reject & & & & \\
\hline DCF2 & 0.821 & & & & \\
\hline DCF3 & 0.803 & 0.636 & 0.856 & 0.897 & \\
\hline DCF4 & 0.819 & & & & \\
\hline DCF5 & 0.845 & & & & \\
\hline ISC1 & Reject & & & & \\
\hline ISC2 & 0.792 & & & & \\
\hline ISC3 & 0.753 & 0.603 & 0.835 & 0.883 & \\
\hline ISC4 & 0.805 & & & & \\
\hline ISC5 & 0.837 & & & & \\
\hline PEU1 & 0.912 & & & & \\
\hline PEU2 & 0.896 & & & & \\
\hline PEU3 & 0.922 & 0.781 & 0.930 & 0.947 & 0,760 \\
\hline PEU4 & 0.877 & & & & \\
\hline PEU5 & 0.808 & & & & \\
\hline PU1 & 0.797 & & & & \\
\hline PU2 & 0.928 & & & & \\
\hline PU3 & 0.877 & 0.626 & 0.818 & 0.885 & 0.601 \\
\hline
\end{tabular}

P-ISSN: 2656-1743 |E-ISSN: 2656-1735

DOI: https://doi.org/10.34288/jri.v3i3.233

\begin{tabular}{lcllll}
\hline $\begin{array}{c}\text { Indi } \\
\text { cator }\end{array}$ & $\begin{array}{c}\text { Outer } \\
\text { Loading }\end{array}$ & AVE & CA & CR & $\mathrm{R}^{2}$ \\
\hline PU4 & 0.873 & & & & \\
\hline PU5 & Reject & & & & \\
\hline ATU1 & 0.804 & & & & \\
\hline ATU2 & 0.712 & & & & \\
\hline ATU3 & Reject & 0.535 & 0.782 & 0.850 & 0.144 \\
\hline ATU4 & Reject & & & & \\
\hline ATU5 & 0.835 & & & & \\
\hline
\end{tabular}

Source: (Sani et al., 2021)

Table 2 below shows the results of the FornellLarcker value analysis for each construct. Based on Table 2, it can be seen that the value of the square root AVE for each construct is greater than the correlation between constructs so that it meets the FornellLarcker criteria. This shows that the construct meets discriminant validity.

Table 2. Fornell \& Lacker

\begin{tabular}{lccccccc}
\hline & ATU & DCF & INV & ISC & OPT & PEU & PU \\
\hline ATU & 0.73 & & & & & & \\
\hline DCF & 0.46 & 0.8 & & & & & \\
\hline INV & 0.32 & 0.77 & 0.84 & & & & \\
\hline ISC & 0.41 & 0.36 & 0.34 & 0.77 & & & \\
\hline OPT & 0.28 & 0.70 & 0.68 & 0.32 & 0.73 & & \\
\hline PEU & 0.36 & 0.84 & 0.73 & 0.35 & 0.75 & 0.88 & \\
\hline PU & 0.21 & 0.66 & 0.77 & 0.37 & 0.67 & 0.79 & 0.79 \\
\hline
\end{tabular}

Source: (Sani et al., 2021)

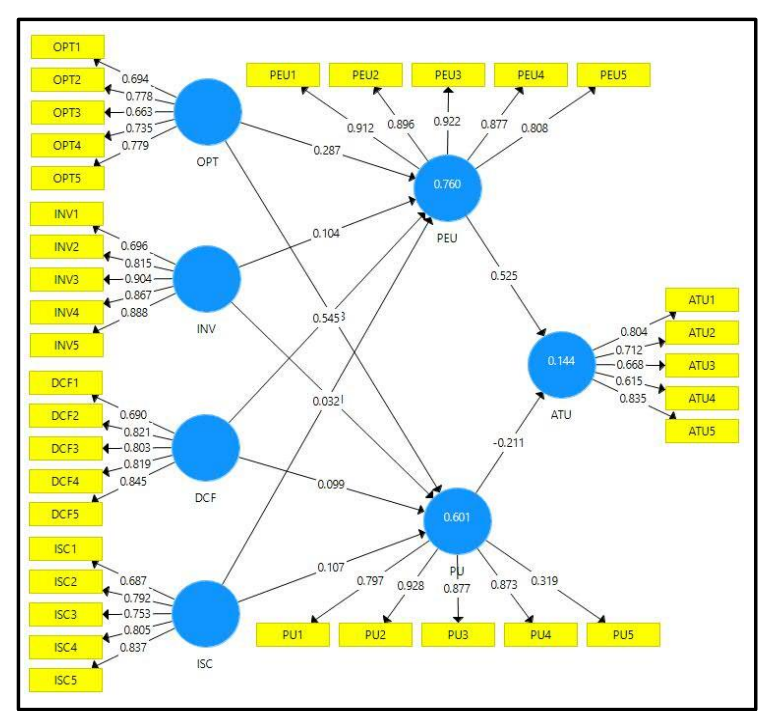

Source: (Sani et al., 2021)

Figure 3. Outer Model Assesment

\section{Structural model (inner model)}

After evaluating the outler model, namely the latent variable measurement model, the next step is to evaluate the structural equation model (inner model), which explains the effect of the independent latent model on the latent dependent variable.

The significance and magnitude of the influence of the independent latent variables. The 
purpose of this test, to determine whether the independent variable affects the latent dependent variable through the T-Statistics. In addition to this test, it is also possible to evaluate the magnitude of the influence of the independent latent variable by looking at the path coefficient of analysis (path coefficient). The significance value used was 1.96 ( significance level $=5 \%$ ) (Hair Jr et al., 2016). So that constructs that have T-Statistics count> 1.96 are declared to have a significant effect.

\begin{tabular}{lccccc}
\multicolumn{7}{c}{ Table 3. Significant test } \\
\hline & $\begin{array}{c}\text { Orign } \\
\text { Sample }\end{array}$ & $\begin{array}{c}\text { Sample } \\
\text { Mean }\end{array}$ & $\begin{array}{c}\text { Stand } \\
\text { Dev }\end{array}$ & T Stat & $\begin{array}{c}\text { P } \\
\text { Values }\end{array}$ \\
\hline DCF ->PEU & 0,55 & 0,53 & 0,07 & 7,00 & $\mathbf{0 , 0 0}$ \\
\hline DCF ->PU & 0,09 & 0,09 & 0,12 & 0,82 & $\mathbf{0 , 4 1}$ \\
\hline INV ->PEU & 0,10 & 0,10 & 0,08 & 1,22 & $\mathbf{0 , 2 2}$ \\
\hline INV ->PU & 0,42 & 0,42 & 0,10 & 3,90 & $\mathbf{0 , 0 0}$ \\
\hline ISC ->PEU & 0,03 & 0,03 & 0,03 & 0,97 & $\mathbf{0 , 3 3}$ \\
\hline ISC ->PU & 0,10 & 0,10 & 0,05 & 1,80 & $\mathbf{0 , 0 7}$ \\
\hline OPT ->PEU & 0,28 & 0,29 & 0,07 & 3,78 & $\mathbf{0 , 0 0}$ \\
\hline OPT ->PU & 0,28 & 0,29 & 0,09 & 2,93 & $\mathbf{0 , 0 0}$ \\
\hline PEU ->ATU & 0,52 & 0,54 & 0,12 & 4,13 & $\mathbf{0 , 0 0}$ \\
\hline PU ->ATU & $-0,21$ & $-0,24$ & 0,17 & 1,22 & $\mathbf{0 , 2 2}$ \\
\hline SOU rCe $($ Sand
\end{tabular}

Source: (Sani et al., 2021)

The path coefficient $(\beta)$ test is carried out to test the $\beta$ value, where the value is at $\beta>0.1$, to state that it has a significant effect. Table 3 shows that five lines have no significant effect, namely DCF $\rightarrow$ PU, $\mathrm{INV} \rightarrow \mathrm{PEU}, \mathrm{ISC} \rightarrow \mathrm{PEU}, \mathrm{ISC} \rightarrow \mathrm{PU}$ and PU $\rightarrow$ ATU While the remaining five paths have a significant effect, namely DCF $\rightarrow$ PEU, INV $\rightarrow$ PU, OPT $\rightarrow$ PEU, $\mathrm{OPT} \rightarrow \mathrm{PU}$ and PEU $\rightarrow$ ATU.

Table 3 shows the accepted hypothesis in the investigation of readiness in using the mobile payment system for shopping at SMEs as an independent variable, and the moderator variables are $\mathrm{DCF} \rightarrow \mathrm{PEU}, \mathrm{INV} \rightarrow \mathrm{PU}, \mathrm{OPT} \rightarrow \mathrm{PEU}, \mathrm{OPT} \rightarrow \mathrm{PU}$, and PEU $\rightarrow$ ATU. The $\mathrm{T}$ Stat value for each hypothesis shows a value above 1.96 . This shows that in terms of optimism for shopping using a mobile payment system, respondents strongly believe that this can work, only from the point of view of shopping safety which is still in doubt. This can be seen in the unaccepted hypothesis, namely ISC $\rightarrow$ PEU and ISC $\rightarrow$ PU.

\section{CONCLUSIONS AND SUGGESTIONS}

\section{Conclusion}

Overall, the test results that have been carried out starting from the measurement model test (outer model) and the structural model test (inner model) are running well. The interest in using a mobile payment in making payments seems to have become a habit in making transactions.
However, there are some things that users still doubt about when making transactions online. The main factor is the security problem in transacting, as shown in the results of the structural model test, which shows that the existing hypothesis is not accepted. The amount of interest of respondents in this study is indicated by the speed with which data is collected, and this shows that the public, especially users of mobile applications, want to know the readiness of users in using applications. The contribution in this study provides additional knowledge in information systems, especially the use of mobile payment applications in making transactions. Application providers will utilize the importance of research to improve the display features and performance of the application.

\section{Suggestion}

This study does not calculate the results of the hypotheses by category but calculates the overall demographic of respondents. This research will continue to be developed by doing categorical calculations based on the age and location of the mobile application users

\section{REFERENCES}

A. Parasuraman , C. L. C. (2014). The Influence of Technology Readiness Index in Entrepreneurial Orientation A Study with Brazilian Entrepreneurs in the United States of America.pdf. Journal of Service Research 17. doi:10.5585/iji.v5i1.150

Abbas, A. E. (2017). Literature review of a cashless society in Indonesia: evaluating the progress. International Journal of Innovation, Management and Technology, 8(3), 193-196.

Acheampong, P., Zhiwen, L., Antwi, H. A., Otoo, A. A. A., Mensah, W. G., \& Sarpong, P. B. (2017). Hybridizing an extended technology readiness index with technology acceptance model (TAM) to predict epayment adoption in Ghana. American Journal of Multidisciplinary Research, 5(2).

Daly, P., \& Walsh, J. S. (2010). Drucker's theory of the business and organisations: challenging business assumptions. Management Decision.

Davis, F. D. (1989). Perceived usefulness, perceived ease of use, and user acceptance of information technology. MIS quarterly, 319-340. 
Drucker, P. F. (2017). The Theory of the Business (Harvard Business Review Classics): Harvard Business Press.

Faisal, A., Handayanna, F., \& Purnamasari, I. (2021). IMPLEMENTATION TECHNOLOGY ACCEPTANCE MODEL (TAM) ON ACCEPTANCE OF THE ZOOM APPLICATION IN ONLINE LEARNING. Jurnal Riset Informatika, 3(2), 85-92.

Hair, J. F., Sarstedt, M., Ringle, C. M., \& Mena, J. A. (2012). An assessment of the use of partial least squares structural equation modeling in marketing research. Journal of the academy of marketing science, 40(3), 414433.

Hair Jr, J. F., Hult, G. T. M., Ringle, C., \& Sarstedt, M. (2016). A primer on partial least squares structural equation modeling (PLS-SEM): Sage Publications.

Husain, T., \& Sani, A. (2020). Kepuasan Pelanggan Toko Online Yang Dipengaruhi Kualitas Produk Dan Layanan. JITK (Jurnal Ilmu Pengetahuan Dan Teknologi Komputer), 5(2), 291-296.

Husain, T., Sani, A., Ardhiansyah, M., \& Wiliani, N. (2020). Online Shop as an interactive media information society based on search engine optimization (SEO). International Journal of Computer Trends \& Technology.

Kam, C. C. S. (2020). Expanded format shows better response consistency than Likert-scale format in the measurement of optimism. Personality and Individual Differences, 152, 109606.

Kusuma, P. O., \& Darma, G. S. (2020). Mobile Payment Transaction on MSMEs. International Research Journal of Management, IT and Social Sciences, 7(3), 104-109.

Nugroho, A. H., Bakar, A., \& Ali, A. (2017). Analysis of technology acceptance model: Case study of Traveloka. Arthatama, 1(1), 27-34.

Nugroho, M. A. (2015). Impact of government support and competitor pressure on the readiness of SMEs in Indonesia in adopting the information technology. Procedia Computer Science, 72, 102-111.

Parasuraman, A. (2000). Technology Readiness Index (TRI) a multiple-item scale to measure readiness to embrace new technologies. Journal of service research, 2(4), 307-320.

Parasuraman, A., \& Colby, C. L. (2015). An updated and streamlined technology readiness index: TRI 2.0. Journal of service research, 18(1), 59-74.

Pesik, T., Worang, F. G., \& Arie, F. V. (2020). Analysis the adoption of Ovo as Smartphone Payment (Case Study: Students And Workers In Manado). Jurnal EMBA: Jurnal Riset Ekonomi, Manajemen, Bisnis Dan Akuntansi, 8(1).

Pratiwi, M. T., \& Indriani, F. (2017). Analisis Pengaruh Technology Readiness Terhadap Minat Menggunakan TCASH di Kota Semarang. Diponegoro University,

Salloum, S. A., \& Al-Emran, M. (2018). Factors affecting the adoption of E-payment systems by university students: Extending the TAM with trust. International Journal of Electronic Business, 14(4), 371-390.

Sani, A., Nawaningtyas, N., Budiyantara, A., Irwansyah, \& Hindardjo, A. (2021). Laporan Akhir Penelitian Mandiri. Jakarta.

Sani, A., \& Wiliani, N. (2019). Faktor Kesiapan dan Adopsi Teknologi Informasi dalam Konteks Teknologi serta Lingkungan pada UMKM di Jakarta. JITK (Jurnal Ilmu Pengetahuan Dan Teknologi Komputer), 5(1), 49-56.

Sinha, M., Majra, H., Hutchins, J., \& Saxena, R. (2019). Mobile payments in India: the privacy factor. International Journal of Bank Marketing.

Subiyakto, A. (2018). Assessing information system integration using combination of the readiness and success models. Bull. Electr. Eng. Inform, 7, 400-410.

Subiyakto, A., Ahlan, A. R., Kartiwi, M., \& Putra, S. J. (2016). Measurement of the information system project success of the higher education institutions in Indonesia: a pilot study. International Journal of Business Information System, 23(2), 229-247. doi:https://doi.org/10.1504/IJBIS.2016.0 78908

Subiyakto, A. a. (2017). Development of the Readiness and Success Model for Assessing the Information System Integration. Paper presented at the The 2nd International Conference on Science and Technology (ICOSAT), Jakarta, Indonesia.

Veblen, T., \& Dowd, D. (2017). The theory of business enterprise: Routledge.

Venkatesh, V., Morris, M. G., Davis, G. B., \& Davis, F. D. (2003). User acceptance of information technology: Toward a unified view. MIS quarterly, 425-478. 
Venkatesh, V., Thong, J. Y., \& Xu, X. (2016). Unified theory of acceptance and use of technology: A synthesis and the road ahead.

Willy Abdillah, J. (2015). Partial Least Square (PLS), Alternatif SEM. 1, 262.

Zhao, Y., Xue, Y.-R., Jin, Y.-F., Li, J.-W., \& He, Y. (2016). The Study of Influencing Factors of Mobile E-commerce Software Use Intention-based on TAM and TRA. International Journal of Grid and Distributed Computing, 9(8), 261274. 